\title{
Bioflocculants' production in a
} biomass-degrading bacterium using untreated corn stover as carbon source and use of bioflocculants for microalgae harvest

\author{
Haipeng Guo ${ }^{1,2}$, Chuntao Hong ${ }^{3}$, Bingsong Zheng ${ }^{4}$, Fan Lu ${ }^{5}$, Dean Jiang ${ }^{2}$ and Wensheng Qin ${ }^{\text {** }}$
}

\begin{abstract}
Background: Bioflocculation has been developed as a cost-effective and environment-friendly method to harvest multiple microalgae. However, the high production cost of bioflocculants makes it difficult to scale up. In the current study, low-cost bioflocculants were produced from untreated corn stover by a biomass-degrading bacterium Pseudomonas sp. GO2.

Results: Pseudomonas sp. GO2 showed excellent production ability of bioflocculants through directly hydrolyzing various biomasses. The untreated corn stover was selected as carbon source for bioflocculants' production due to its highest flocculating efficiency compared to that when using other biomasses as carbon source. The effects of fermentation parameters on bioflocculants' production were optimized via response surface methodology. According to the optimal model, an ideal flocculating efficiency of $99.8 \%$ was obtained with the fermentation time of $130.46 \mathrm{~h}$, initial pH of 7.46 , and biomass content of $0.64 \%$. The relative importance of carboxymethyl cellulase and xylanase accounted for $51.8 \%$ in the process of bioflocculants' production by boosted regression tree analysis, further indicating that the bioflocculants were mainly from the hydrolysates of biomass. Biochemical analysis showed that it contained 59.0\% polysaccharides with uronic acid (34.2\%), 32.1\% protein, and $6.1 \%$ nucleic acid in the bioflocculants, which had an average molecular weight as $1.33 \times 10^{6} \mathrm{Da}$. In addition, the bioflocculants showed the highest flocculating efficiency at a concentration of $12.5 \mathrm{mg} \mathrm{L}^{-1}$ and were stable over broad ranges of $\mathrm{pH}$ and temperature. The highest flocculating efficiencies obtained for Chlorella zofingiensis and Neochloris oleoabundans were 77.9 and $88.9 \%$, respectively.
\end{abstract}

Conclusions: The results indicated that Pseudomonas sp. GO2 can directly utilize various untreated lignocellulolytic biomasses to produce low-cost bioflocculants, which showed the high efficiency to harvest two green microalgae in a low GO2 fermentation broth/algal culture ratio.

Keywords: Biomass-degrading bacterium, Pseudomonas sp. GO2, Corn stover, Bioflocculants, Microalgae harvest

\section{Background}

Owing to the enormous demand for energy and the shortage of traditional fossil fuels, renewable and sustainable fuels have received increasing attention to alleviate dependence on the fossil fuels. Microalgae have been

\footnotetext{
*Correspondence: wqin@lakeheadu.ca

${ }^{1}$ Department of Biology, Lakehead University, Thunder Bay, ON P7B 5E1, Canada

Full list of author information is available at the end of the article
}

considered as promising renewable feedstocks owing to their fast growth rate, high lipid accumulation as well as non-competition with food supply [1, 2]. Although biofuel production from microalgae has been widely researched in the last few decades, it is still hindered by high production costs, which mainly comes from the processes of cultivation, harvest, drying, lipid extraction, and transesterification $[3,4]$. The harvest of algae, which usually accounts for more than $30 \%$ of total costs, has been 
one of the biggest challenges in the process of algal biofuel production $[5,6]$. Furthermore, costs may increase according to the size of microalgal cells, the density of the algal culture, and the intensity of negative charge on the surface of algae [7]. Therefore, an economic and effective method is urgently necessary for algal harvesting to reduce total costs [5].

A variety of methods, such as centrifugation [8], filtration [9], ultrafiltration [10], sedimentation [5], and flotation [11], have been used to harvest algal cells. However, high-capital equipment and operational costs, high energy consumption, or heavy dependence on algal species have hampered large-scale commercialization of these microalgal harvesting methods $[5,12]$. The harvest of microalgae through flocculation, which can form heavy aggregates by neutralizing the algal surface's negative charges using various flocculants and thus increase the rate of settling [13], has been proposed as the most reliable and suitable harvesting method for multiple algae species, even at low biomass concentrations $[6,14]$. Flocculation induced by chemicals, including inorganic and organic chemicals, has been used for the effective harvest of various microalgal strains. However, inorganic flocculants are toxic and have negative effects on algal viability, thus limiting algal recycling and reuse [15]. Moreover, most organic flocculants are mainly derived from fossil fuels or edible crops, which may further aggravate the problems of fossil fuel and food shortages, and associated environmental risks $[5,16]$.

Bioflocculants' production by bacteria in nature has been suggested as a cost-effective and environmentfriendly method of producing flocculants to effectively harvest multiple algae $[17,18]$. These bioflocculants mainly consisted of polysaccharides, proteins, and nucleic acids [19]. Some bacterial species like Bacillus sp. [20], Rhodococcus sp. [21], Solibacillus sp. [22], Arthrobacter sp. [23], and Pseudomonas sp. [24] have been reported to produce bioflocculants, and applied to harvest algae. However, for commercial-scale bioflocculants' production from bacteria, large amounts of nutrients and sugars are required $[18,24]$. To minimize the production cost, various wastewaters and hydrolysates of agricultural waters have been successfully used for bacterial growth and bioflocculants' production [24, 25]. Recently, some lignocellulolytic enzyme-producing bacteria have been found to possess the ability to produce bioflocculants through directly utilizing untreated renewable lignocellulosic biomass. Liu et al. [18] reported that Cellulosimicrobium cellulans L804 can produce bioflocculants from untreated corn stover by secreting CMCase and xylanase. Bioflocculants produced by Bacillus agaradhaerens $\mathrm{C} 9$ using untreated rice bran have been shown to be highly efficient in harvesting algae [26]. Here, a novel biomass-degrading bacterium isolated from paper mill sludge showed efficient bioflocculants' production using various untreated lignocellulosic biomasses as carbon source. Then, the bioflocculants' production conditions were further optimized via response surface methodology (RSM) and evaluated by boosted regression tree (BRT) analysis. In addition, their flocculating properties and applications in two types of microalgal harvesting were also evaluated in this study.

\section{Results and discussion}

Evaluating the biomass degradation ability of $\mathrm{GO} 2$

One isolate, GO2, which could produce bioflocculants by directly degrading various untreated biomasses, was isolated from paper mill sludge and finally identified as Pseudomonas sp. according to the morphological and phylogenetic characteristics of this strain, as well as the sequence of $16 \mathrm{~S}$ rRNA (Additional file 1: Fig. S1). The sequence has been submitted to NCBI (https://www. ncbi.nlm.nih.gov/), and the accession number was given as MF448527. The biomass hydrolysis ability of this strain was evaluated by Gram's iodine staining on plates using different lignocellulolytic biomasses as the sole carbon source (Fig. 1). Gram's iodine staining has been regarded as an economic, fast, and environmentally friendly qualitative method for evaluating the hydrolysis ability of microorganisms on an agar plate [27]. Gram's iodine forms a bluish-black compound with carbohydrate polymers but not with their hydrolysates (Halo region). In this study, the strain $\mathrm{GO} 2$ produced an obvious halo region with the halo diameters ranging from 2.4 to $2.9 \mathrm{~cm}$ in the agar plate containing untreated agave, corn stover, Miscanthus, wheat bran, and wood dust (Fig. 1). In addition, similar halo regions can be formed with the halo diameters of 2.8 and $2.7 \mathrm{~cm}$ in the agar plates containing $\mathrm{CMC}$ and xylan, respectively, indicating the strain GO2 was capable of degrading the biomass through secreting CMCase and xylanase [28, 29]. A number of Pseudomonas strains have been reported to produce various extracellular lignocellulolytic enzymes, which showed excellent ability to hydrolyze various lignocellulosic feedstocks [30, 31].

\section{Selecting the best lignocellulose biomass for bioflocculants' production}

Lignocellulose biomass, which is mainly made up of complex carbohydrate polymers including cellulose, hemicellulose, and lignin, has been widely used for the production of biofuels and other biomass-derived valueadded chemicals and bioproducts [32, 33]. In this study, four main lignocellulose biomasses including agave, corn stover, Miscanthus, and wheat bran were selected to evaluate the bioflocculants' production ability using the 


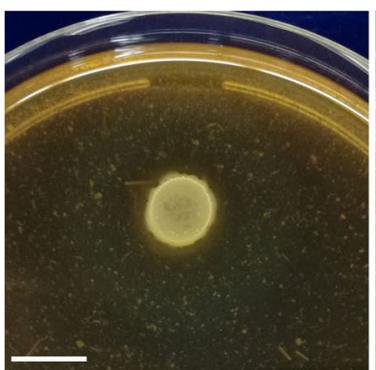

Agave

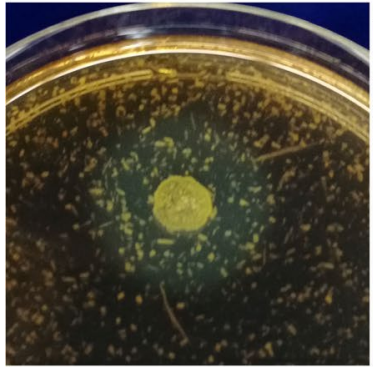

Wood

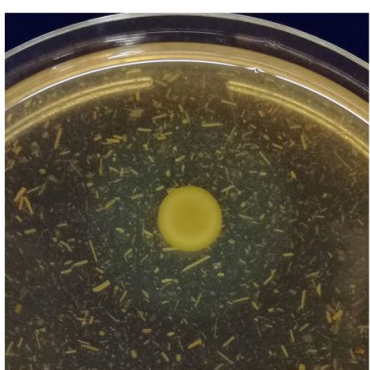

Corn

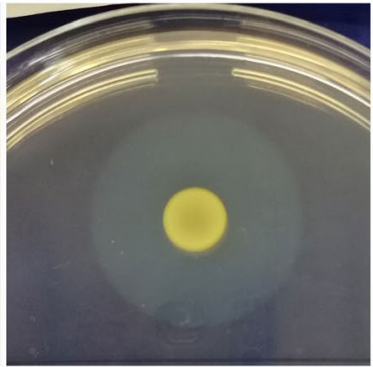

CMC

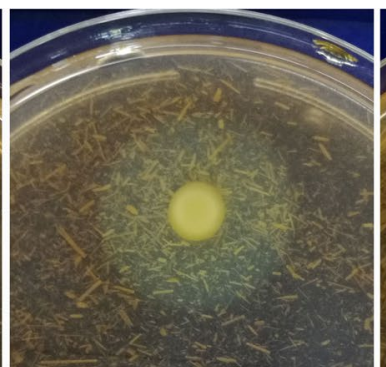

Miscanthus (Mis)

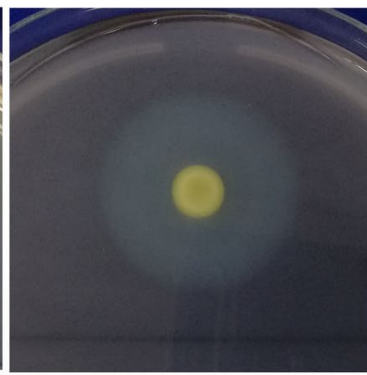

Xylan

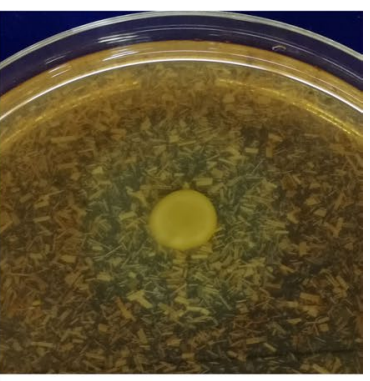

Wheat

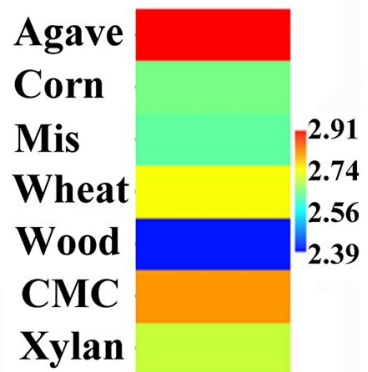

Halo diameter (cm)

Fig. 1 Evaluation of the hydrolysis ability of Pseudomonas sp. GO2 using different biomass, CMC, or xylan as carbon source by Gram's iodine staining. The yellow plaque in the center of plate indicates the bacterial size, and the halo region indicates that carbohydrate polymers are hydrolyzed. The halo diameter is shown by matrix plot. Bar $=1 \mathrm{~cm}$

biomass-degrading strain Pseudomonas sp. GO2. The maximum flocculating efficiency with the value of $95.1 \%$ was obtained using $0.5 \%(\mathrm{w} / \mathrm{v})$ corn stover after $120 \mathrm{~h}$ of fermentation, while the highest flocculating efficiencies were $95.0,94.4$, and $94.7 \%$ in the presence of $0.5 \%$ $(\mathrm{w} / \mathrm{v})$ agave, Miscanthus, and wheat bran, respectively, after $120-144 \mathrm{~h}$ of incubation (Fig. 2). Moreover, the maximum flocculating efficiency was only $23.5 \%$ after $48 \mathrm{~h}$ of fermentation in the absence of biomass (Data not shown), representing that the bioflocculant was primarily produced from the hydrolysates of lignocellulose biomass by Pseudomonas sp. GO2. The flocculating efficiency of GO2 induced by $0.5 \%$ untreated corn stover was almost always higher and more stable than that by other biomasses after 48-196 h of incubation (Fig. 2), and its maximum flocculating efficiency $(95.1 \%)$ was significantly higher than that of Cellulosimicrobium cellulans L804 induced by $2.0 \%$ corn stover (90.9\%) [18] and Bacillus agaradhaerens C9 produced by rice bran (87.2\%) [26]. Therefore, untreated corn stover was selected as the best lignocellulose biomass candidate for bioflocculants' production in the subsequent experiments.

\section{Optimization of the bioflocculants' production using GO2}

The effects of incubation time, biomass content, and initial $\mathrm{pH}$ on flocculating efficiency of GO2 fermentation

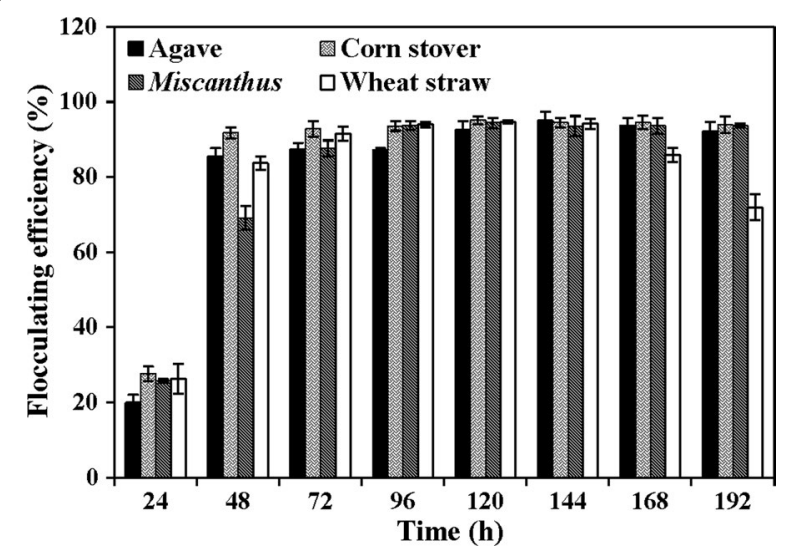

Fig. 2 Bioflocculants' production by Pseudomonas sp. GO2 using $0.5 \%$ untreated agave, corn stover, Miscanthus, or wheat bran biomass as carbon source. Strain GO2 was cultured at $37^{\circ} \mathrm{C}$ and 200 rpm for 8 days, and the supernatants were collected each day to measure the flocculating efficiency by means of kaolin clay as substrate. Data are the means of four replicates \pm SE

were optimized by RSM. Variance analysis (ANOVA) suggested that the model was significant because the $F$ value of the model was 5.46, which stands for only a $0.7 \%$ probability to come up because of noise (Table 1$)$. The correlation coefficient $\left(R^{2}\right)$ was recorded up to 0.9390 , 
Table 1 ANOVA of the quadratic model coefficient of flocculating efficiency

\begin{tabular}{lcccll}
\hline Source & Sum of squares & $\boldsymbol{D} \boldsymbol{F}$ & Mean square & $\boldsymbol{F}$ value & Prob $\boldsymbol{F}$ \\
\hline Model & 8719.77 & 9 & 968.86 & 5.46 & 0.0070 \\
$A$ & 2433.14 & 1 & 2433.14 & 13.72 & 0.0041 \\
$B$ & 61.99 & 1 & 61.99 & 0.35 & 0.5675 \\
$C$ & 2599.69 & 1 & 2599.69 & 14.66 & 0.0033 \\
AB & 197.34 & 1 & 197.34 & 1.11 & 0.3164 \\
AC & 34.71 & 1 & 34.71 & 0.2 & 0.6676 \\
BC & 17.72 & 1 & 17.72 & 0.100 & 0.7584 \\
$A^{2}$ & 54.69 & 1 & 54.69 & 0.31 & 0.5909 \\
$B^{2}$ & 640.74 & 1 & 640.74 & 3.61 & 0.0865 \\
$C^{2}$ & 1203.5 & 1 & 1203.5 & 6.78 & 0.0263 \\
Residual & 1773.86 & 10 & 1773.86 & - & - \\
\hline$R^{2}$ & & &
\end{tabular}

$R^{2}$ 0.9390, $A$ fermentation time (h), $B$ initial $\mathrm{pH}, C$ biomass content (\%), $D F$ degree of freedom

which represented that the correlation of experimental and predicated values was significant in the model [21]. Moreover, the low "Pro $>F$ " value $(<0.0500)$ demonstrated that the model terms were significant (Table 1). According to the optimal model, the fitted equation of flocculating efficiency during fermentation process is finally shown as follows: an excellent flocculating efficiency [36, 37]. The excessive biomass content may refine oxygen transfer in the cultural medium, which affected the cell growth, enzymatic secretion, and bioflocculants' production of bacteria [26]. In addition, excess nutrition caused by high biomass contents also leads to the decrease of flocculating efficiency [21].

To understand the relative importance of incubation time, CMCase activity, xylanase activity, biomass content, and initial $\mathrm{pH}$ on flocculating efficiency, a BRT modeling analysis, which combines with statistical and machine learning techniques [38], was performed. The selected model was fitted when learning rate was set as 0.001, tree complexity as 4 , and bag fraction as 1.5 . The model showed a training data correlation coefficient of 0.82 and a cross-validation correlation coefficient of 0.75 , indicating that this model is significant $[39,40]$. The relative importance analysis indicated that CMCase activity was the most important variable on flocculating efficiency (39.5\%), followed by biomass content (26.0\%), incubation time (20.2\%), xylanase activity (12.3\%), and initial pH (1.9\%) (Fig. 4). The relative importance of CMCase and xylanase activity accounted for $51.8 \%$ of all variables, further indicating that the bioflocculants' production of GO2 was mainly from the conversion of biomass by lignocellulosic enzymes [26]. The dependence plot of

$$
\begin{aligned}
\text { Flocculating activity }= & -97.74941+0.87408[\text { Time }]+49.61787[\text { Initial } \mathrm{pH}] \\
& -41.92902[\text { Biomass content }]-0.059458[\text { Time }] \times[\text { Initial pH }] \\
& +0.028872[\text { Time }] \times[\text { Biomass content }]+0.47619[\text { Initial pH }] \\
& \times[\text { Biomass content }]-1.28178 \mathrm{E}-003[\text { Time }]^{2} \\
& -3.35267[\text { Initial } \mathrm{pH}]^{2}+6.03965[\text { Biomass content }]^{2}
\end{aligned}
$$

As shown in Fig. 3, the flocculating efficiency can achieve an ideal level of $99.8 \%$ under the optimal conditions of fermentation time of $130.46 \mathrm{~h}$, initial $\mathrm{pH}$ at 7.46 , and biomass content at $0.64 \%(\mathrm{w} / \mathrm{v})$. The flocculating efficiency was positively related to incubation time, but decreased slightly with further extension of culture time, possibly due to the limited growth of cells caused by consumption of various nutrients [34] and the production of proteases caused by cell lysis [35]. Moreover, it seemed that the biomass content negatively affected the increase of flocculating efficiency, and the initial $\mathrm{pH}$ only showed a little influence on the bioflocculant production (Fig. 3). The high biomass content may markedly change the ratio of carbon and nitrogen, which played a crucial role in cell growth and bioflocculant production [21, 26]. High carbon/nitrogen ratio is beneficial to cell growth but decreases flocculating efficiency and the accumulation of bioflocculants. The low carbon/nitrogen ratio can maintain a stable $\mathrm{pH}$ of the culture medium, thus keeping biomass content showed that flocculating efficiency was positively related when the biomass content was less than $2.5 \%$, and the biomass content, which ranged from 2.5 to $4.0 \%$, made almost no contribution to bioflocculants' production (Fig. 4b). This was similar to that the low biomass content was beneficial to produce bioflocculants according to the RSM model (Fig. 3b). The flocculating efficiency was significantly increased after $108 \mathrm{~h}$ of incubation, which may mainly depend on the production of lignocellulosic enzymes and thereby release available substrates to produce bioflocculants $[18,41]$. In addition, the model indicated that the optimal initial $\mathrm{pH}$ for flocculating efficiency ranged from 5.0 to 8.3 , which is consistent with the initial $\mathrm{pH}$ close to neutralization leading to the highest flocculating rate $[24,42]$.

\section{Characteristics of the bioflocculants produced by $\mathrm{GO} 2$}

The bioflocculants from GO2 consisted of $59.0 \%$ total polysaccharides, $32.1 \%$ protein, and $6.1 \%$ nucleic acid (Table 2). 


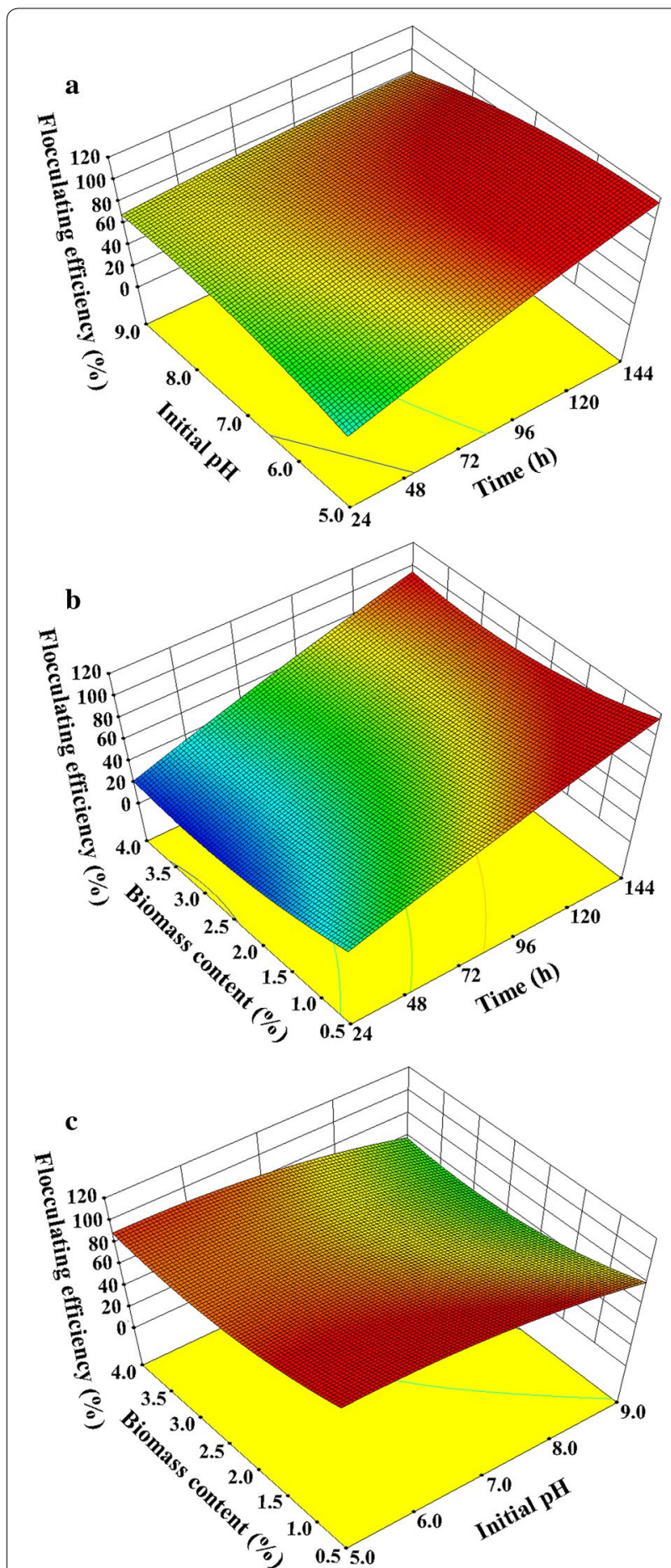

Fig. 3 Effects of fermentation time, initial $\mathrm{pH}$, and biomass content on bioflocculants' production using Pseudomonas sp. GO2 via RSM. The matrix included a total of 20 experiments, and all experiments were performed at $37^{\circ} \mathrm{C}$ and $200 \mathrm{rpm}$. a Effects of fermentation time and initial pH. b Effects of fermentation time and biomass content. $\mathbf{c}$ Effects of initial $\mathrm{pH}$ and biomass content
Our result was similar to the main compositions of bioflocculants secreted by other bacterial strains [18, 43]. Further analysis indicated that total polysaccharides contained $58.0 \%$ uronic acid. The higher contents of proteins and uronic acid in the bioflocculants can offer more carboxyl groups, which can increase the number of effective sites for particles' adsorption $[18,44]$. The maximum bioflocculants yield was $316 \mathrm{mg} \mathrm{g}^{-1}$ biomass when untreated corn stover was added into the medium. The viscosity of $1.0 \mathrm{~g} \mathrm{~L}^{-1}$ bioflocculants is $1.352 \mathrm{cPs}$, and the average molecular weight of these bioflocculants is $1.33 \times 10^{6} \mathrm{Da}$. In addition, the bioflocculants showed a negative zeta potential with the value of $-57.38 \mathrm{mV}$, and its charge density is -1.007 meq g $^{-1}$ bioflocculants (Table 2).

To further verify that the functional groups existed in the bioflocculants, the spectra of the purified bioflocculants were measured in the $4000-600 \mathrm{~cm}^{-1}$ region (Additional file 1: Fig. S2). A big absorption band was found at $3275 \mathrm{~cm}^{-1}$, indicating the existence of hydroxyl and amine groups, and a weak $\mathrm{C}-\mathrm{H}$ stretching of methyl, methylene, or methane group at $2928 \mathrm{~cm}^{-1}$ [45]. The absorption signals at 1630 and $1450 \mathrm{~cm}^{-1}$ are the typical characteristics of carboxyl groups, representing the presence of proteins and amino-sugars [13]. The absorption peak at $1045 \mathrm{~cm}^{-1}$ represents a $\mathrm{C}-\mathrm{O}-\mathrm{C}$ stretching vibration of ester linkage, and the weak peak at $881 \mathrm{~cm}^{-1}$ means $\beta$-glycosidic linkages between the sugar monomers, and it has been reported that the wave numbers between 1200 and $800 \mathrm{~cm}^{-1}$ are the main features of all sugar derivatives [46]. The results further confirmed that the bioflocculants predominantly consist of polysaccharides and proteins.

\section{Effects of dosage, $\mathrm{pH}$, temperature, and metal ions on flocculating activity}

To determine the lowest amount of bioflocculants with the highest flocculating efficiency, a series of dosage concentrations ranging from 1.25 to $18.75 \mathrm{mg} \mathrm{L}^{-1}$ were selected to estimate the flocculating efficiency. The results showed the highest flocculating efficiency (94.7\%) was obtained with a dosage of $12.5 \mathrm{mg} \mathrm{L}^{-1}$, and dosage concentrations of $8.75-17.5 \mathrm{mg} \mathrm{L}^{-1}$ resulted in more than $90 \%$ flocculating efficiency (Fig. 5a). Low dosage of bioflocculants usually led to inadequate bridging between particles, while higher bioflocculants concentrations increased the repulsion between particles because of the excessive import of negatively charged polysaccharides [18]. In addition, high dosage of bioflocculants caused the increase in the viscosity of solution, which can also inhibit the sedimentation of floccules [13]. The extracted bioflocculants showed an extensive $\mathrm{pH}$ range 

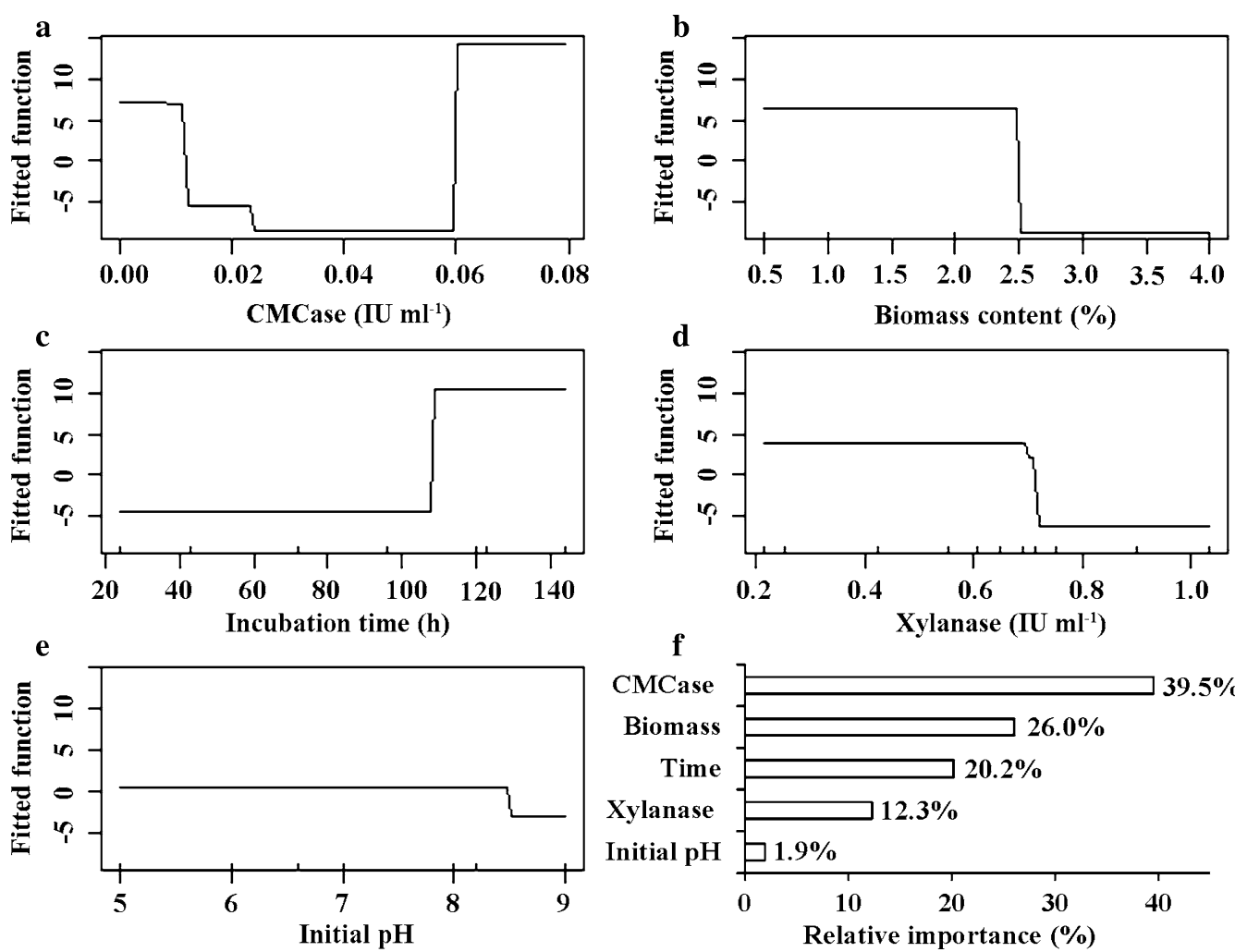

Fig. 4 Partial dependence plots of the five predictor variables in the BRT model for bioflocculant production and their relative importance. a CMCase activity; b biomass content; $\mathbf{c}$ incubation time; $\mathbf{d}$ xylanase activity; e initial $\mathrm{pH} ; \mathbf{f}$ relative importance of the explanatory variables. Rug plots at the inside bottom of graph showed distribution of sample sites along that variable

Table 2 The compositions and characteristics of the bioflocculants produced from $0.5 \%(\mathrm{w} / \mathrm{v})$ untreated corn stover by Pseudomonas sp. GO2

\begin{tabular}{ll}
\hline Compositions & \\
Polysaccharide & $59.0 \pm 3.84 \%$ \\
Protein & $32.1 \pm 2.61 \%$ \\
Nucleic acid & $6.1 \pm 0.90 \%$ \\
Uronic acid & $34.2 \pm 1.85 \%$ \\
Characteristics & \\
Maximum yield & $316 \pm 10.8 \mathrm{mg} \mathrm{g}^{-1} \mathrm{dry} \mathrm{biomass}$ \\
Viscosity & $1.352 \pm 0.008 \mathrm{CPs}^{\left.1.0 \mathrm{~g} \mathrm{~L}^{-1}\right)}$ \\
Molecular weight & $1.33 \times 10^{6} \mathrm{Da}$ \\
Charge density & $-1.007 \pm 0.016 \mathrm{meq} \mathrm{g}^{-1}$ bioflocculants \\
Zeta potential & $-57.38 \pm 0.18 \mathrm{mV}$ \\
\hline
\end{tabular}

for flocculating kaolin clay (Fig. 5b). All measured $\mathrm{pH}$ values (3-13) achieved over $80 \%$ flocculating efficiency. $\mathrm{pH}$ values below 8 achieved more than $90 \%$ flocculating efficiency (Fig. 5b). pH affected the electronic states of the bioflocculants, thus influencing the flocculation efficiency [47]. The slight decrease in flocculation efficiency at $\mathrm{pH} 9$ and 10 may be attributed to the weakening of the spatial charge arrangements of these bioflocculants under these $\mathrm{pH}$ conditions [43]. Moreover, the GO2 bioflocculants exhibited excellent characteristics of thermostability, with over $85 \%$ flocculating efficiency at all tested temperatures $\left(4-80{ }^{\circ} \mathrm{C}\right)$. These are consistent with most polysaccharide-dependent bioflocculants being more stable than protein- and nucleic acid-dependent ones $[48,49]$. The superior $\mathrm{pH}$ and temperature tolerance of these bioflocculants indicated they could have a wide variety of industrial uses regardless of the $\mathrm{pH}$ and temperature of the solutions, thus making them cost effective [43]. Furthermore, the flocculating efficiency was significantly enhanced by monovalent cations $\left(\mathrm{Na}^{+}\right.$and $\left.\mathrm{K}^{+}\right)$, bivalent cations $\left(\mathrm{Ca}^{2+}\right.$ and $\left.\mathrm{Mg}^{2+}\right)$, and low concentration $\mathrm{Al}^{3+}$, while it was markedly inhibited by high concentration $\mathrm{Al}^{3+}$ and all tested $\mathrm{Fe}^{3+}$ concentrations (Fig. 6). Metal cations can stabilize and neutralize the residual negative charge formed by certain functional groups, and help to form the bridges between particles, thus improving flocculating efficiency [50]. The highest flocculating efficiency was obtained using $10 \mathrm{mg} \mathrm{L}^{-1} \mathrm{Ca}^{2+}$ (Fig. 6b), which has been found to be the best cation stimulator for 

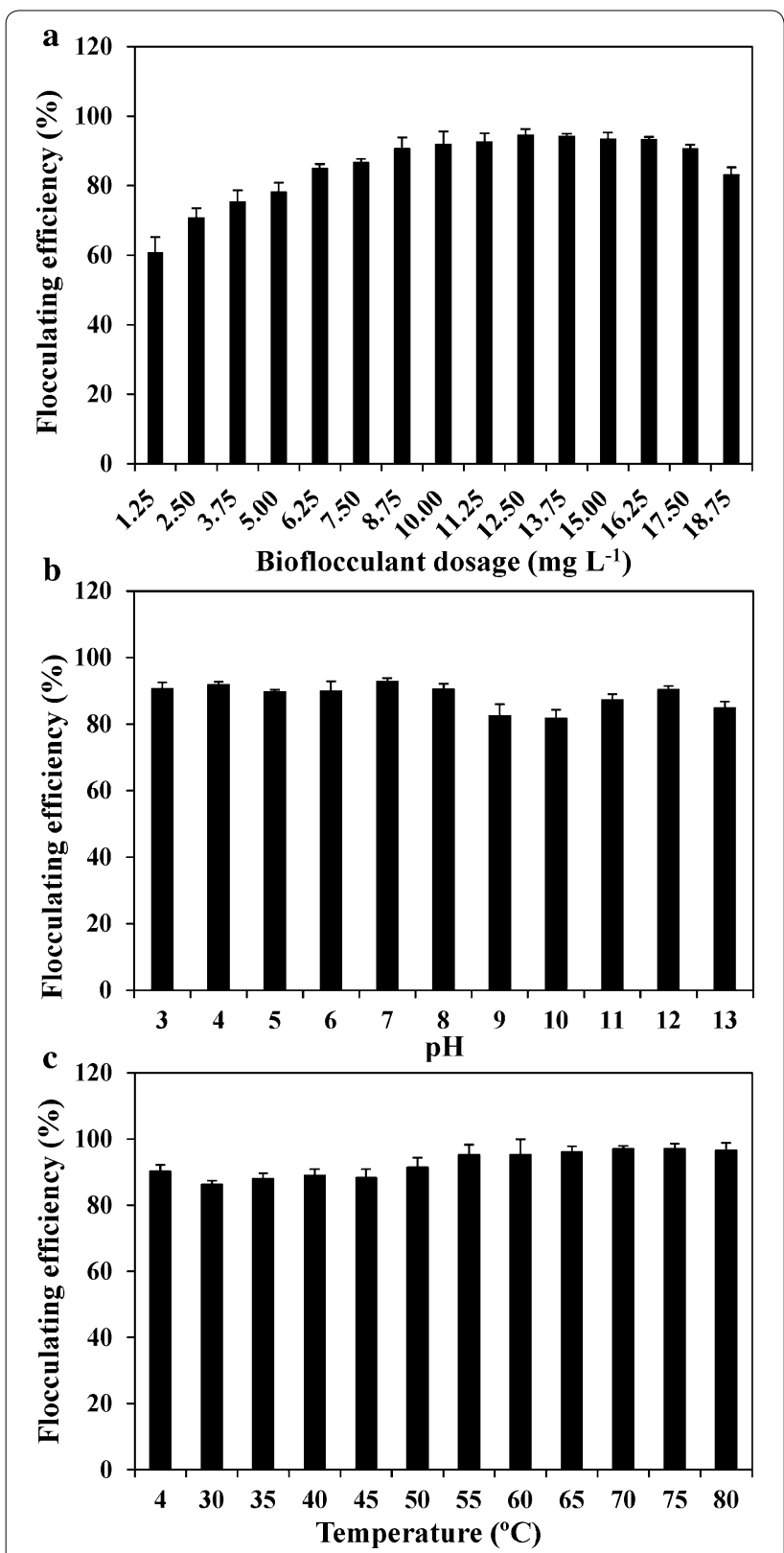

Fig. 5 Effects of bioflocculant dosage, $\mathrm{pH}$, and temperature on flocculating efficiency using kaolin clay suspension. a Dosage; $\mathbf{b} \mathrm{pH} ; \mathbf{c}$ temperature. Data are the means of four replicates \pm SE

most bioflocculants $[18,19]$. The poor flocculation in the presence of $\mathrm{Fe}^{3+}$ (Fig. 6c) may be due to the alteration of the surface charge and the decrease in adsorption sites of particles [43].

\section{Application of the bioflocculants $\mathrm{GO} 2$ in two green microalgal harvests}

Green microalgae have been regarded as an emerging feedstock to produce biodiesel, but the commercialization of microalgal biofuel production has not been realized because of its high production cost [51]. In this study, a cost-effective algal harvesting method using bioflocculants produced by Pseudomonas sp. GO2 was investigated. To save as much cost as possible, the fermentation broth of GO2 was directly mixed with algal culture in different volume ratios to evaluate its flocculating efficiency. The results showed the flocculating efficiencies of two green microalgae were significantly enhanced by increasing the ratio of GO2 fermentation broth and algal culture (Fig. 7A). The maximum flocculating efficiency was $77.9 \%$ at the $\mathrm{GO} 2$ fermentation broth/algal culture ratio of $3.5 / 40$ for Chlorella zofingiensis (C. zofingiensis), while it was up to $88.9 \%$ for Neochloris oleoabundans (N. oleoabundans) at the corresponding ratio of 3/40 (Fig. 7A). The dosage of GO2 bioflocculants was significantly lower than that of other bacterial bioflocculants. Cellulosimicrobium cellulans L804 started to show the effective flocculating ability only when the fermentation broth and algal culture ratio was up to $1 / 6$ for flocculating Chlamydomonas reinhardtii and 1/2 for flocculating Chlorella minutissima [18]. The corresponding ratio of $3 / 1$ was needed by using the fermentation broth of Solibacillus silvestris W01 although 90\% microalga Nannochloropsis oceanica can be harvested [22]. Moreover, the images showed that the algal cells were separately scattered before flocculation (Fig. 7B), while they were connected as large aggregates after flocculation (Fig. 7C), thus settling easily due to faster sedimentation [13].

\section{The possible mechanism of flocculation for harvesting microalgae}

Based on the characteristics analysis and the results of microalgae harvest, the possible flocculation mechanism of bioflocculants produced by GO2 was concluded as follows (Fig. 8): first, the bioflocculants produced by GO2 presented a negative zeta potential and charge density, which is the same with microalgae [14], indicating that microalgal harvest mechanism through these bioflocculants depended on sweeping and bridging, rather than electrical neutralization [52]; second, the cations were indispensable in the process of flocculation, further indicating bridging and patching played major roles in this flocculation. The cations can stabilize and neutralize the negative change of functional groups, which helped to overcome the electrostatic repulsion between bioflocculants and microalgal cells, and enhance flocculation; third, the high molecular weight bioflocculants can also stabilize the suspension and tend to flocculate through bridging. Bridging easily occurs when the extended distance of flocculant from the surface of particles into the solution is greater than the distance from the repulsion of interparticles [53]. 

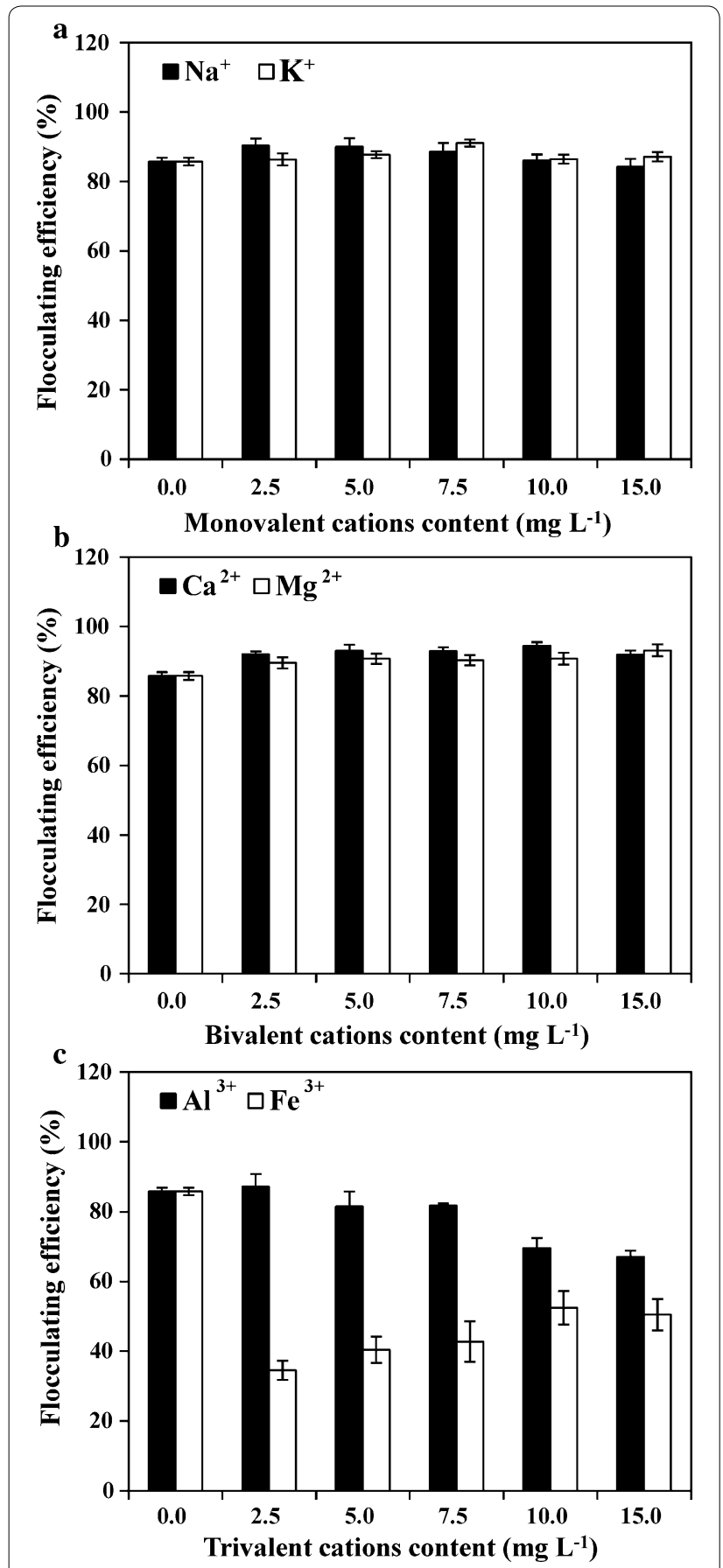

Fig. 6 Effects of various metal ions $\left(0-15 \mathrm{mg} \mathrm{L}^{-1}\right)$ on flocculating efficiency using kaolin clay suspension at $\mathrm{pH} 7.0$ with the bioflocculant dosage of $12.5 \mathrm{mg} \mathrm{L}^{-1}$. a Monovalent cations $\left(\mathrm{Na}^{+}\right.$and $\left.\mathrm{K}^{+}\right)$; $\mathbf{b}$ bivalent cations $\left(\mathrm{Ca}^{2+}\right.$ and $\left.\mathrm{Mg}^{2+}\right)$, and $\mathbf{c}$ trivalent cations $\left(\mathrm{Al}^{3+}\right.$ and $\left.\mathrm{Fe}^{3+}\right)$. Data are the means of four replicates $\pm \mathrm{SE}$

\section{Conclusions}

Low-cost bioflocculant was produced from untreated corn stover by a biomass-degrading bacterium Pseudomonas sp. GO2. The gram's iodine staining and BRT
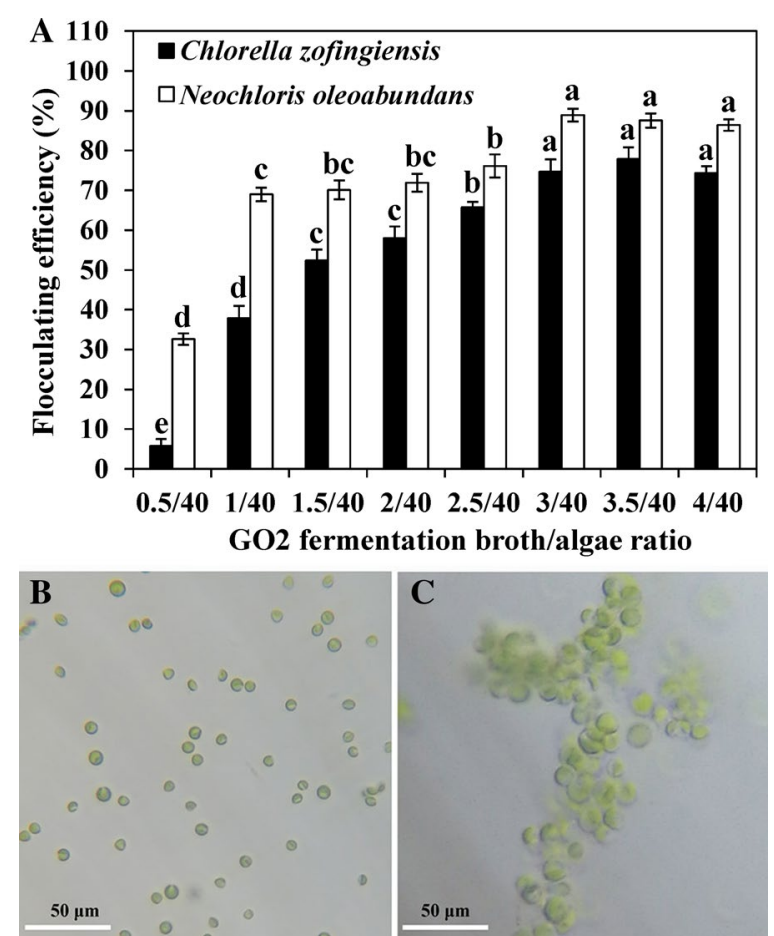

Fig. 7 A Effects of different volume ratios of $\mathrm{GO} 2$ fermentation broth/algal culture on the flocculating efficiencies of two green microalgae, Chlorella zofingiensis and Neochloris oleoabundans. Microscopic views of Neochloris oleoabundans cells before (B) and after (C) bioflocculation. Data are the means of four replicates $\pm \mathrm{SE}$, and bars with different letters are significantly different at $p<0.05$ according to Duncan's multiple range test. Bar $=50 \mu \mathrm{m}$

analysis showed that $\mathrm{GO} 2$ directly utilized untreated biomass as carbon source to produce bioflocculant. An ideal flocculating efficiency of $99.8 \%$ was obtained under the optimal conditions (fermentation time $130.46 \mathrm{~h}$, initial $\mathrm{pH}$ 7.46, and corn stover 0.64\%). The extracted bioflocculant showed a high $\mathrm{pH}$ and temperature tolerance with a maximum flocculating efficiency of $94.7 \%$ at the dosage of $12.5 \mathrm{mg} \mathrm{L}^{-1}$. Furthermore, the low-cost bioflocculant can effectively harvest two green microalgae in a low GO2 fermentation broth/algal culture ratio.

\section{Methods}

\section{Isolation and identification of bioflocculant-producing} bacteria

A biomass-degrading bacterium was isolated from paper mill sludge by Gram's iodine staining method according to our previous description [28]. When culturing the strain in the mineral salt medium $\left(\mathrm{NaNO}_{3} 0.1 \mathrm{~g} \mathrm{~L}^{-1}\right.$, $\mathrm{K}_{2} \mathrm{HPO}_{4} 0.1 \mathrm{~g} \mathrm{~L}^{-1}, \mathrm{KCl} 0.1 \mathrm{~g} \mathrm{~L}^{-1}, \mathrm{MgSO}_{4} 0.05 \mathrm{~g} \mathrm{~L}^{-1}$, yeast extract $0.05 \mathrm{~g} \mathrm{~L}^{-1}$, and peptone $0.3 \mathrm{~g} \mathrm{~L}^{-1}$ ) containing $0.5 \%$ various untreated lignocellulosic biomasses, the fermentation broths became highly transparent and viscous, 


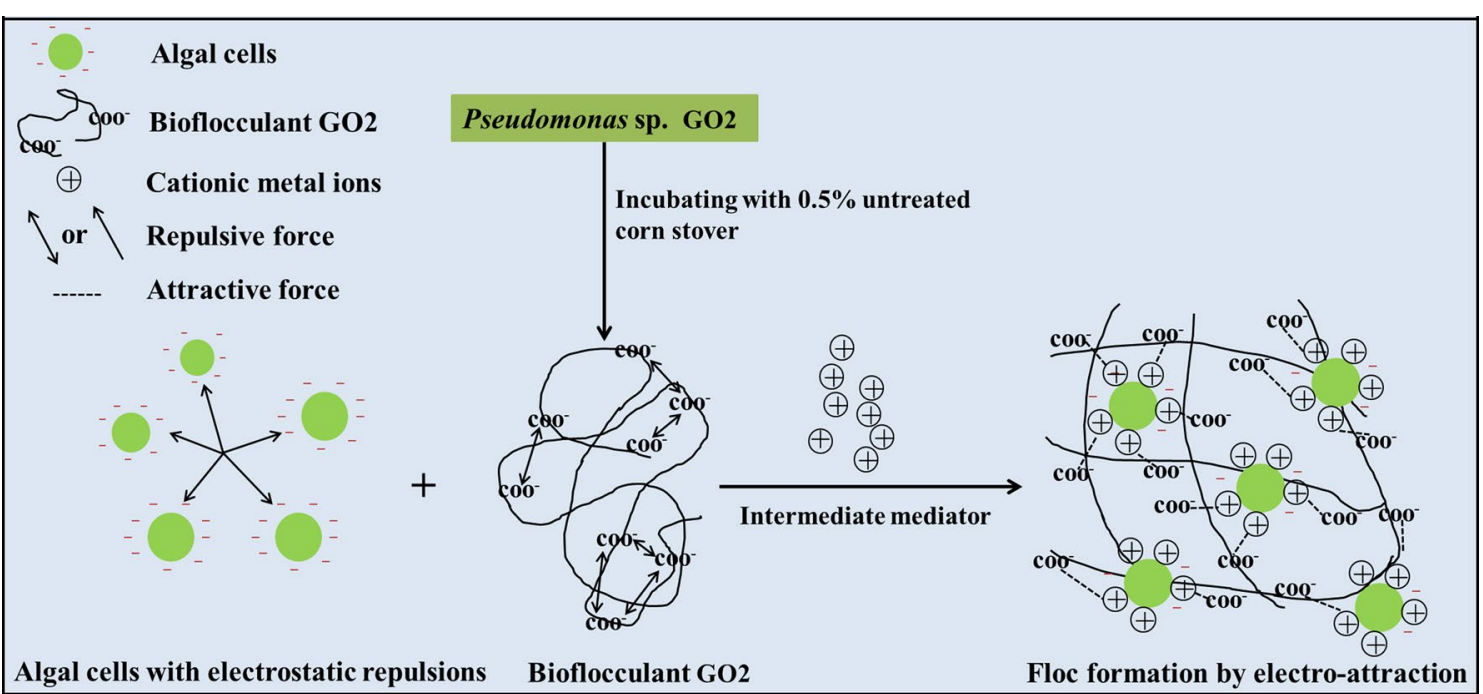

Fig. 8 The possible mechanism of bioflocculants produced by GO2 in flocculating microalgal cells

and biomass was compact and deposited at the bottom of flask after $48 \mathrm{~h}$ of incubation at $37^{\circ} \mathrm{C}$ and $200 \mathrm{rpm}$. The strain was finally confirmed as a bioflocculant-producing bacterium by evaluating the flocculating rate of the fermentation broth. To identify the species of this bacterium, its genome was extracted using a Bacteria DNA kit (Bio Basic, Markham, Ontario, Canada). The 16S rRNA gene was amplified through polymerase chain reaction (PCR) using the primers: HAD-1 (5'-GACTCCTACGGGAGGCAGCAT-3') and E1115R (5'-AGG GTTGCGCTCGTTGCGGG-3'). Then the PCR products were purified for sequencing.

\section{Evaluation of biomass degradation ability and enzyme activity assay}

The biomass degradation ability of this strain was evaluated by using various lignocellulosic biomasses as carbon source as described by Guo et al. [28]. In brief, $5 \mu \mathrm{L}$ of overnight-grown culture was inoculated on agar plates containing above mineral salt medium, $1.5 \%$ agar, and $0.5 \%$ agave, corn stover, Miscanthus, wheat bran, wood dust, CMC or beechwood xylan (Sigma-Aldrich, St. Louis, MO, USA). After incubation at $37^{\circ} \mathrm{C}$ for $48 \mathrm{~h}$, all of the plates were treated with Gram's iodine reagent for 3-5 min. Then the diameters of the halo region $(D)$ were measured on a centimeter scale.

The activities of CMCase and xylanase were evaluated by using CMC and xylan as substrate, respectively, as descripted by Guo et al. [28]. The concentrations of reducing sugar were determined using the 3,5-dinitrosalicylic acid (DNS, Sigma-Aldrich, St. Louis, MO, USA) reagent described by Miller [54]. A range of D-glucose and D-xylose $\left(0-1.2 \mathrm{mg} \mathrm{mL}^{-1}\right)$ concentrations were used to plot the standard curves for the hydrolysis production of CMC and xylan, respectively.

\section{Measurement of flocculating efficiency}

The flocculating efficiency was tested as described by Kurane et al. [55] with some minor modifications. In brief, $200 \mu \mathrm{L}$ of sample and $1.0 \mathrm{~mL}$ of $10 \%(\mathrm{w} / \mathrm{v}) \mathrm{CaCl}_{2}$ were mixed with $40 \mathrm{~mL}$ of $0.5 \%$ (w/v) kaolin clay (SigmaAldrich, St. Louis, MO, USA) solution in a $50 \mathrm{~mL}$ glass-beaker, shaken at $100 \mathrm{rpm}$ for $2 \mathrm{~min}$, and left to stand for $1 \mathrm{~min}$ at $25 \pm 2{ }^{\circ} \mathrm{C}$. The optical density (OD) of the upper phase was measured at $550 \mathrm{~nm}$ using a microplate spectrophotometer (Epoch, Bio Tek Instruments, Inc., Vermont, USA). The flocculating efficiency was calculated as follows: Flocculating efficiency $(\%)=(A-B) / A \times 100 \times D$, where $A$ and $B$ are the optical densities of the control and the samples at $550 \mathrm{~nm}$, respectively, and $D$ is the dilution time of the supernatant of the fermentation broth.

\section{Optimization of bioflocculant production and boosted regression tree (BRT) analysis}

To estimate the effects of various biomasses on the production of bioflocculants using Pseudomonas sp. GO2, the strain was cultivated in the mineral salt medium containing $0.5 \%(\mathrm{w} / \mathrm{v})$ untreated agave, corn stover, Miscanthus and wheat bran at $37{ }^{\circ} \mathrm{C}$ with agitation at $200 \mathrm{rpm}$, and the flocculating efficiency was monitored every day for 8 days. To determine the effects of incubation time, initial $\mathrm{pH}$ and biomass content on the production of bioflocculants, an experimental design matrix was 
performed via RSM using the Design-Expert software (Version 8.0.6., Stat-Ease Inc., Minneapolis, USA) according to our previous description [45]. The matrix included a total of 20 experiments, and all experiments were executed at $37{ }^{\circ} \mathrm{C}$ with shaking at $200 \mathrm{rpm}$. The fermentation broths were harvested every day and centrifuged at $12,000 \mathrm{~g}$ for $3 \mathrm{~min}$. Then the supernatant was used to determine the flocculating efficiency, and CMCase and xylanase activities.

To partition independent influences of incubation time, CMCase activity, xylanase activity, biomass concentration, and initial $\mathrm{pH}$ on bioflocculants' production, The BRT model was built by the R-software (version 2.10.1, $\mathrm{R}$ development Core team 2009) with the ' $\mathrm{gbm}$ ' package using a Bernoulli error structure [56], and with brt. functions [39]. The relative influence of each parameter in the model was measured according to the number of times that variable was selected for splitting in the tree, weighted by the squared improvement and averaged over all trees [57].

\section{Extraction and characteristics of the bioflocculants}

The bioflocculants produced by $\mathrm{GO} 2$ were purified as descripted by Xiong et al. [58] with some minor modifications. In brief, GO2 strain was cultured using untreated corn stover as carbon source to produce bioflocculants in the optimal conditions. Then the fermentation broth was stored at $4{ }^{\circ} \mathrm{C}$ for at least $6 \mathrm{~h}$ to settle the solids. The supernatants were carefully transferred to a new flask and mixed with two volumes of pre-cooling ethanol, and the resultant sediment was collected by centrifugation at $5000 \mathrm{~g}$ for $10 \mathrm{~min}$, washed three times with $75 \%$ ethanol, and finally lyophilized to acquire the dryness bioflocculants.

To analyze the compositions of bioflocculants, the total polysaccharides were determined using the anthrone-sulfuric acid method, and D-glucose was selected as the standard sample [59]; the total protein was obtained by using the Bradford Protein Assay Kit (Bio Basic Canada Inc., Markhan, ON, CA) according to our previous description [60]; the uronic acid content was measured by cabazoic sulfuric acid method with $\mathrm{D}-(+)$ galacturonic acid as the standard sample [61]; while the nucleic acid content was quantified by the spectrophotometer. The molecular weight, charge density and Zeta potential of the bioflocculants were determined as descripted by Wang et al. [62]. The viscosity of the bioflocculants was measured using an OB-C218 Ubbelohde Viscometer (Cannon instrument company, USA) according to the method of Cui et al. [63]. The spectrum of bioflocculant was measured by a Bruker Tensor 37 FTIR Spectrophotometer (Bruker Optics, Inc., Billerica, MA) according to our previous description [45].

\section{Flocculating properties of the extracted bioflocculant}

To understand the flocculating properties of bioflocculants, the effects of bioflocculants dosage, $\mathrm{pH}$, temperature, and various metal ions on the flocculating efficiency of kaolin clay solution were recorded. The dosage of bioflocculants was set to range from 1.25 to $18.75 \mathrm{mg} \mathrm{L}^{-1}$. For the measurement of optimal $\mathrm{pH}$ and temperature, the flocculating efficiencies were assayed at various $\mathrm{pH}$ values (3-13) and various temperatures $\left(4-80^{\circ} \mathrm{C}\right)$. To investigate the effects of various metal ions, the monovalent cations $\left(\mathrm{Na}^{+}\right.$and $\left.\mathrm{K}^{+}\right)$, bivalent cations $\left(\mathrm{Ca}^{2+}\right.$ and $\left.\mathrm{Mg}^{2+}\right)$, and trivalent cations $\left(\mathrm{Al}^{3+}\right.$ and $\left.\mathrm{Fe}^{3+}\right)$ at the concentrations of $2.5,5.0,7.5,10.0$, and $15.0 \mathrm{mg} \mathrm{L}^{-1}$ were used.

\section{Evaluation the effect of the bioflocculant on the harvest of microalgae}

Two green microalgal strains C. zofingiensis and N. oleoabundans were obtained from Dr. Lu at Hubei University of Technology and Dr. Chirs Lan at the University of Ottawa, respectively. The cells were grown in BG-11 medium under the conditions of the room temperature $\left(25 \pm 1{ }^{\circ} \mathrm{C}\right.$ ) with a light/dark cycle of $16: 8 \mathrm{~h}$ (cool-white fluorescent light intensity of $100 \pm 2 \mu \mathrm{mol} \mathrm{m}^{-2} \mathrm{~s}^{-1}$ ), and a constant shaking at $150 \mathrm{rpm}$. After 2 weeks of incubation, the biomass yields of $C$. zofingiensis and $N$. oleoabundans were about 1.8 and $2.0 \mathrm{~g} \mathrm{~L}^{-1}$ dry weight, respectively, and the algal culture was used for the harvest experiment.

The flocculating efficiencies of the two green microalgae (C. zofingiensis and N. oleoabundans) were evaluated by directly incubating the $\mathrm{GO} 2$ fermentation broth with algal culture. Different volumes of the fermentation broth $(0.5-4 \mathrm{~mL})$ were mixed with $40 \mathrm{~mL}$ algal culture containing $1 \mathrm{~mL} 10 \% \mathrm{CaCl}_{2}$ solution. The mixture was stirred at $100 \mathrm{rpm}$ for $2 \mathrm{~min}$, and allowed to settle for $10 \mathrm{~min}$ at room temperature. Then the OD of the upper phase was measured at $680 \mathrm{~nm}$ using a microplate spectrophotometer (Epoch, Bio Tek Instruments, Inc., Vermont, USA). The flocculating efficiency of the microalgae was calculated as follows: flocculating efficiency $(\%)=(A-B) / A \times 100 \times D$, where $A$ and $B$ are the optical densities of the control and the samples at $680 \mathrm{~nm}$, respectively; $D$ is the dilution time of the supernatant of the fermentation broth.

The microscopic images of $N$. oleoabundans cells before, and after flocculation using the $\mathrm{GO} 2$ fermentation broth were observed using an Olympus BX51 microscope (Olympus Optical, Tokyo, Japan) as descripted by Guo et al. [28]. In brief, the cells were harvested by centrifugation at $4000 \mathrm{~g}$ for $5 \mathrm{~min}$ and resuspended in equal volume of deionized water after washing three times with deionized water. Then $20 \mu \mathrm{L}$ of appropriate diluted algae cells were attached to a clean glass slide, and picture was taken. 


\section{Statistical analysis}

All the experiments were analyzed in quadruplicate, and the data are shown as mean \pm SD. Statistical analysis was performed by one-way analysis of variance using the program, SPSS (SPSS Inc., USA, version 13.0). The matrix plot of the halo diameter was performed by means of the Past software (version 3.16) [64].

\section{Additional file}

Additional file 1: Fig. S1. Phylogenetic tree of Pseudomonas sp. GO2. $16 \mathrm{~S}$ rRNA gene sequences were retrieved by BLAST searches in NCBI and subjected to phylogenetic analysis using the neighbor-joining method with MEGA6 using 1000 bootstraps. Fig. S2. Fourier transform infrared spectrum of the bioflocculants produced by Pseudomonas sp. GO2 strain.

\section{Abbreviations}

BRT: boosted regression tree; CMC: carboxymethyl cellulose; CMCase: carboxymethyl cellulase; DNS: 3,5-dinitrosalicylic acid; RSM: response surface methodology.

\section{Authors' contributions}

HPG designed the experiments, carried out the study, analyzed the data, and drafted the manuscript. CTH, BSZ, and FL helped to analyze these data and draft the manuscript. DAJ and WSQ participated in the design of the experiments and revising the manuscript. All authors read and approved the final manuscript.

\section{Author details}

${ }^{1}$ Department of Biology, Lakehead University, Thunder Bay, ON P7B 5E1, Canada. ${ }^{2}$ State Key Laboratory of Plant Physiology and Biochemistry, College of Life Sciences, Zhejiang University, Hangzhou 310058, China. ${ }^{3}$ Academy of Agricultural Sciences of Ningbo City, Ningbo 315040, China. ${ }^{4}$ State Key Laboratory of Subtropical Silviculture, Zhejiang A \& F University, Hangzhou 311300, China. ${ }^{5}$ School of Biological Engineering, Hubei University of Technology, Wuhan 430068, China.

\section{Acknowledgements}

Authors would like to thank Dr. Lu at Hubei University of Technology and Dr. Chirs Lan at the University of Ottawa for providing the green microalgae. The authors also thank Andrew Linklater for assistance in editing the manuscript to improve the language.

\section{Competing interests}

The authors declare that they have no competing interests.

\section{Availability of supporting data}

The dataset supporting the conclusions of this article was included within the article.

\section{Ethics approval and consent to participate}

Not applicable.

\section{Funding}

This work was supported by the Natural Sciences and Engineering Research Council of Canada (Grant number RGPIN-2017-05366) to WSQ, and the China Scholarship Council (Grant number 201506320044) to HPG.

\section{Publisher's Note}

Springer Nature remains neutral with regard to jurisdictional claims in published maps and institutional affiliations.

Received: 12 October 2017 Accepted: 1 December 2017

Published online: 20 December 2017
References

1. Borowitzka MA. High-value products from microalgae-their development and commercialisation. J Appl Phycol. 2013;25:743-56.

2. Klok AJ, Martens DE, Wijffels RH, Lamers PP. Simultaneous growth and neutral lipid accumulation in microalgae. Bioresour Technol. 2013;134:233-43

3. Pragya N, Pandey KK, Sahoo P. A review on harvesting, oil extraction and biofuels production technologies from microalgae. Renew Sustain Energy Rev. 2013;24:159-71.

4. Slade R, Bauen A. Micro-algae cultivation for biofuels: cost, energy balance, environmental impacts and future prospects. Biomass Bioenergy. 2013:53:29-38

5. Milledge $\mathrm{J}$, Heaven S. A review of the harvesting of micro-algae for biofuel production. Rev Environ Sci Bio/Technol. 2013;12:165-78.

6. Uduman N, Qi Y, Danquah MK, Forde GM, Hoadley A. Dewatering of microalgal cultures: a major bottleneck to algae-based fuels. J Renew Sustain Energy. 2010;2:012701.

7. Leite GB, Abdelaziz AE, Hallenbeck PC. Algal biofuels: challenges and opportunities. Bioresour Technol. 2013;145:134-41.

8. Sim T-S, Goh A, Becker E. Comparison of centrifugation, dissolved air flotation and drum filtration techniques for harvesting sewage-grown algae. Biomass. 1988;16:51-62.

9. Danquah MK, Ang L, Uduman N, Moheimani N, Forde GM. Dewatering of microalgal culture for biodiesel production: exploring polymer flocculation and tangential flow filtration. J Chem Technol Biotechnol. 2009;84:1078-83.

10. Zhang $X, H u$ Q, Sommerfeld M, Puruhito $E_{1}$ Chen $Y$. Harvesting algal biomass for biofuels using ultrafiltration membranes. Bioresour Technol. 2010;101:5297-304

11. Coward T, Lee JG, Caldwell GS. Development of a foam flotation system for harvesting microalgae biomass. Algal Res. 2013;2:135-44.

12. Odjadjare EC, Mutanda T, Olaniran AO. Potential biotechnological application of microalgae: a critical review. Crit Rev Biotechnol. 2017:37:37-52.

13. Wang L, Ma F, Qu Y, Sun D, Li A, Guo J, Yu B. Characterization of a compound bioflocculant produced by mixed culture of Rhizobium radiobacter $\mathrm{F} 2$ and Bacillus sphaeicus F6. World J Microbiol Biotechnol. 2011;27:2559-65.

14. Van Haver L, Nayar S. Polyelectrolyte flocculants in harvesting microalgal biomass for food and feed applications. Algal Res. 2017;24:167-80.

15. Garzon-Sanabria AJ, Davis RT, Nikolov ZL. Harvesting Nannochloris oculata by inorganic electrolyte flocculation: effect of initial cell density, ionic strength, coagulant dosage, and media pH. Bioresour Technol. 2012;118:418-24.

16. Ho Y, Norli I, Alkarkhi AF, Morad N. Characterization of biopolymeric flocculant (pectin) and organic synthetic flocculant (PAM): a comparative study on treatment and optimization in kaolin suspension. Bioresour Technol. 2010;101:1166-74.

17. Kim D-G, La H-J, Ahn C-Y, Park Y-H, Oh H-M. Harvest of Scenedesmus sp. with bioflocculant and reuse of culture medium for subsequent highdensity cultures. Bioresour Technol. 2011;102:3163-8.

18. Liu W, Zhao C, Jiang J, Lu Q, Hao Y, Wang L, Liu C. Bioflocculant production from untreated corn stover using Cellulosimicrobium cellulans L804 isolate and its application to harvesting microalgae. Biotechnol Biofuels. 2015;8:170

19. Wu J-Y, Ye H-F. Characterization and flocculating properties of an extracellular biopolymer produced from a Bacillus subtilis DYU1 isolate. Process Biochem. 2007:42:1114-23.

20. Ndikubwimana T, Zeng X, Liu Y, Chang J-S, Lu Y. Harvesting of microalgae Desmodesmus sp. F51 by bioflocculation with bacterial bioflocculant. Algal Res. 2014;6:186-93.

21. Peng L, Yang C, Zeng G, Wang L, Dai C, Long Z, Liu H, Zhong Y. Characterization and application of bioflocculant prepared by Rhodococcus erythropolis using sludge and livestock wastewater as cheap culture media. Appl Microbiol Biotechnol. 2014:98:6847-58.

22. Wan C, Zhao X-Q, Guo S-L, Alam MA, Bai F-W. Bioflocculant production from Solibacillus silvestris W01 and its application in cost-effective harvest of marine microalga Nannochloropsis oceanica by flocculation. Bioresour Technol. 2013:135:207-12. 
23. Mabinya LV, Cosa S, Nwodo U, Okoh Al. Studies on bioflocculant production by Arthrobacter sp. Raats, a freshwater bacteria isolated from Tyume River, South Africa. Int J Mol Sci. 2012;13:1054-65.

24. Liu W, Hao Y, Jiang J, Zhu A, Zhu J, Dong Z. Production of a bioflocculant from Pseudomonas veronii L918 using the hydrolyzate of peanut hull and its application in the treatment of ash-flushing wastewater generated from coal fired power plant. Bioresour Technol. 2016;218:318-25.

25. Zhong C, Xu A, Chen L, Yang X, Yang B, Hong W, Mao K, Wang B, Zhou J. Production of a bioflocculant from chromotropic acid waste water and its application in steroid estrogen removal. Colloids Surf B Biointerfaces. 2014;122:729-37.

26. Liu C, Hao Y, Jiang J, Liu W. Valorization of untreated rice bran towards bioflocculant using a lignocellulose-degrading strain and its use in microalgal biomass harvest. Biotechnol Biofuels. 2017;10:90.

27. Kasana RC, Salwan R, Dhar H, Dutt S, Gulati A. A rapid and easy method for the detection of microbial cellulases on agar plates using Gram's iodine. Curr Microbiol. 2008;57:503-7.

28. Guo H, Chen H, Fan L, Linklater A, Zheng B, Jiang D, Qin W. Enzymes produced by biomass-degrading bacteria can efficiently hydrolyze algal cell walls and facilitate lipid extraction. Renew Energy. 2017;109:195-201.

29. Woo HL, Hazen TC, Simmons BA, DeAngelis KM. Enzyme activities of aerobic lignocellulolytic bacteria isolated from wet tropical forest soils. Syst Appl Microbiol. 2014;37:60-7.

30. Cheng C-L, Chang J-S. Hydrolysis of lignocellulosic feedstock by novel cellulases originating from Pseudomonas sp. CL3 for fermentative hydrogen production. Bioresour Technol. 2011;102:8628-34.

31. Maki ML, Idrees A, Leung KT, Qin W. Newly isolated and characterized bacteria with great application potential for decomposition of lignocellulosic biomass. J Mol Microbiol Biotechnol. 2012;22:156-66.

32. FitzPatrick M, Champagne P, Cunningham MF, Whitney RA. A biorefinery processing perspective: treatment of lignocellulosic materials for the production of value-added products. Bioresour Technol. 2010;101:8915-22.

33. Morgan HM, Bu Q, Liang J, Liu Y, Mao H, Shi A, Lei H, Ruan R. A review of catalytic microwave pyrolysis of lignocellulosic biomass for value-added fuel and chemicals. Bioresour Technol. 2017;230:112-21.

34. Wang JD, Levin PA. Metabolism, cell growth and the bacterial cell cycle. Nat Rev Microbiol. 2009;7:822.

35. Wang Z, Wang Y, Zhang D, Li J, Hua Z, Du G, Chen J. Enhancement of cell viability and alkaline polygalacturonate lyase production by sorbitol cofeeding with methanol in Pichia pastoris fermentation. Bioresour Technol. 2010;101:1318-23.

36. Lin J, Harichund C. Production and characterization of heavy-metal removing bacterial bioflocculants. Afr J Biotechnol. 2012;11:9619-29.

37. Liu W, Wang K, Li B, Yuan H, Yang J. Production and characterization of an intracellular bioflocculant by Chryseobacterium daeguense W6 cultured in low nutrition medium. Bioresour Technol. 2010;101:1044-8.

38. Friedman J, Hastie T, Tibshirani R. Additive logistic regression: a statistical view of boosting (with discussion and a rejoinder by the authors). Ann Stat. 2000;28:337-407.

39. Elith J, Leathwick JR, Hastie T. A working guide to boosted regression trees. J Anim Ecol. 2008;77:802-13.

40. Jorda H, Bechtold M, Jarvis N, Koestel J. Using boosted regression trees to explore key factors controlling saturated and near-saturated hydraulic conductivity. Eur J Soil Sci. 2015;66:744-56.

41. Bhalla A, Bansal N, Kumar S, Bischoff KM, Sani RK. Improved lignocellulose conversion to biofuels with thermophilic bacteria and thermostable enzymes. Bioresour Technol. 2013;128:751-9.

42. Aljuboori AHR, Idris A, Abdullah N, Mohamad R. Production and characterization of a bioflocculant produced by Aspergillus flavus. Bioresour Technol. 2013;127:489-93.
43. Makapela B, Okaiyeto K, Ntozonke N, Nwodo UU, Green E, Mabinya LV, Okoh Al. Assessment of Bacillus pumilus isolated from fresh water milieu for bioflocculant production. Appl Sci. 2016;6:211.

44. Gao J, Bao H-Y, Xin M-X, Liu Y-X, Li Q, Zhang Y-F. Characterization of a bioflocculant from a newly isolated Vagococcus sp. W31. J Zhejiang Univ Sci B. 2006;7:186-92.

45. Guo H, Wu Y, Hong C, Chen H, Chen X, Zheng B, Jiang D, Qin W. Enhancing digestibility of Miscanthus using lignocellulolytic enzyme produced by Bacillus. Bioresour Technol. 2017;245:1008-15

46. Pathak M, Sarma HK, Bhattacharyya KG, Subudhi S, Bisht V, Lal B, Devi A. Characterization of a novel polymeric bioflocculant produced from bacterial utilization of $n$-hexadecane and its application in removal of heavy metals. Front Microbiol. 2017;8:170.

47. Pan Y, Shi B, Zhang Y. Research on flocculation property of bioflocculant PG. a21 Ca. Mod Appl Sci. 2009;3:106.

48. Patil SV, Patil CD, Salunke BK, Salunkhe RB, Bathe G, Patil DM. Studies on characterization of bioflocculant exopolysaccharide of Azotobacter indicus and its potential for wastewater treatment. Appl Biochem Biotechnol. 2011;163:463-72.

49. Salehizadeh H, Shojaosadati S. Extracellular biopolymeric flocculants: recent trends and biotechnological importance. Biotechnol Adv. 2001;19:371-85.

50. Salehizadeh H, Vossoughi M, Alemzadeh I. Some investigations on bioflocculant producing bacteria. Biochem Eng J. 2000;5:39-44.

51. Feng $P$, Deng Z, Hu Z, Fan L. Lipid accumulation and growth of Chlorella zofingiensis in flat plate photobioreactors outdoors. Bioresour Technol. 2011;102:10577-84.

52. Zhang C, Wang X, Wang Y, Li Y, Zhou D, Jia Y. Synergistic effect and mechanisms of compound bioflocculant and $\mathrm{AlCl}_{3}$ salts on enhancing Chlorella regularis harvesting. Appl Microbiol Biotechnol. 2016;100:5653.

53. Levy N, Magdassi S, Bar-Or Y. Physico-chemical aspects in flocculation of bentonite suspensions by a cyanobacterial bioflocculant. Water Res. 1992;26:249-54.

54. Miller GL. Use of dinitrosalicylic acid reagent for determination of reducing sugar. Anal Chem. 1959;31:426-8.

55. Kurane R, Hatamochi K, Kakuno T, Kiyohara M, Hirano M, Taniguchi Y. Production of a bioflocculant by Rhodococcus erythropolis S-1 grown on alcohols. Biosci Biotechnol Biochem. 1994;58:428-9.

56. Ridgeway G. Generalized boosted models: a guide to the gbm package. Update. 2007;1:2007.

57. Friedman JH, Meulman JJ. Multiple additive regression trees with application in epidemiology. Stat Med. 2003;22:1365-81.

58. Xiong Y, Wang Y, Yu Y, Li Q, Wang H, Chen R, He N. Production and characterization of a novel bioflocculant from Bacillus licheniformis. Appl Environ Microbiol. 2010;76:2778-82.

59. Leyva A, Quintana A, Sánchez M, Rodríguez EN, Cremata J, Sánchez JC. Rapid and sensitive anthrone-sulfuric acid assay in microplate format to quantify carbohydrate in biopharmaceutical products: method development and validation. Biologicals. 2008;36:134-41.

60. Guo H, Lin C, Wang S, Jiang D, Zheng B, Liu Y, Qin W. Characterization of a novel laccase-producing Bacillus sp. A4 and its application in Miscanthus degradation. Bioresources. 2017;12:4776-94.

61. Barker S, Young N. Isolation of hyaluronic acid by gel filtration on agarose. Carbohydr Res. 1966;2:363-70.

62. Wang S, Konduri MK, Hou Q, Fatehi P. Cationic xylan-METAC copolymer as a flocculant for clay suspensions. RSC Adv. 2016;6:40258-69.

63. Cui L, Goodwin C, Gao W, Liao B. Effect of cold water temperature on membrane structure and properties. J Membr Sci. 2017;540:19-26.

64. Hammer $\varnothing$, Harper D, Ryan P. PAST: paleontological statistics software package for education and data analysis. Paleontol Electron. 2001;4:1-9. 